\title{
RESENHA
}

\section{EM SALA DE AULA: LITERATURA PARA JOVENS ${ }^{1}$}

\author{
Geraldina Porto WITTER ${ }^{2}$ \\ UMC / PUC-Campinas
}

Trata-se aqui de uma obra que se encaixa na categoria Livro de Autores, que foram coordenados por Elliot e Dupuis, docentes de universidades dos USA, de estados diversos e dedicados aos estudo da leitura. Elliot é docente de alfabetização, atuando na Indiana University of Pennsylvania e Dupuis é professora emérita de Educação na Penn State University e docente da University Park, também da Pennsylvania.

Após breves agradecimentos e apresentação dos autores, Dupuis assume o texto de Introdução, no qual explicita os jovens adultos como leitores cujos interesses e habilidades ainda não estão suficientemente maduros, mas que estão cientes do seu processo de maturação, de seus problemas, dos problemas de suas famílias e da sua comunidade, muitos dos quais estão fora do controle dos jovens. Estão cientes de que é preciso aprender a tomar decisões e resolver problemas, pois são habilidades necessárias para suas carreiras.

O livro compreende três sessões, devidamente introduzidas, um apêndice, um glossário de idéias de professores, créditos, índice de autores de textos científicos, índice de autores de textos literários para jovens e índice de conteúdos. Todos os componentes adicionais auxiliam os leitores na releitura ou na busca de informações específicas.

A Primeira Parte do livro enfoca o responder à leitura, que deve ser o traço marcante da leitura nas classes que aglutinam jovens adultos. Este responder implica falare escrever. Novos métodos estão disponíveis para que isso se concretize. A parte é composta por três capítulos.

O primeiro é assinado por Poe e enfoca o responder escrevendo, especialmente resenhando livros; ilustra a proposta por meio de uma revisão dos muitos projetos que coordenou nesta área. Apresenta diretrizes gerais para fazer resenhas de obras literárias compreendendo: referências bibliográficas, informações sobre o conteúdo, orientações para redação do texto e identificação do autor da resenha. Orienta como funcionar como editor. Recomenda e orienta o professor e/ou leitor a consultar mais de uma resenha de um mesmo livro, a selecionar, da produção de alunos, as que merecem publicação. Apresenta várias idéias para trabalhar em classe e para outros encaminhamentos, com resenhas.

Robb escreve o Segundo Capítulo, no qual explora o escrever sobre livros como

(1) Elliot, J.B. \& Dupuis, M.M. (eds), (2002). Young adult literature in the classroom. Reading it, teaching it, loving it. Newark: IRA, 248 p.

(2) Profa. Dra. do Curso de pós-Graduação em Psicologia - PUC-Campinas. Endereço para correspondência: Av. John Boyd Dunlop s/n - Jardim Ipaussurama - CEP 13059-900 - Programa de Pós-Graduação em Psicologia - PUC-Campinas. 
forma de pensar sobre os mesmos, do estilo, dos conteúdos, da assimilação à interpretação. Vai além, propõe o uso deste conhecimento pelo jovem em situações sociais e na sua vida pessoal.

O tema tem continuidade no texto de Samuels (Capítulo 3), que procura relacionar TV, literatura e atividades de sala de aula na produção de sínteses de textos acadêmicos. Explora a diversidade cultural que é refletida nos livros de literatura para jovens. Apresenta um quadro, muito útil para a análise e para a pesquisa, no qual aparecem arrolados os principais termos usados para caracterizar os personagens de obras literárias. Finaliza lembrando que as aulas de hoje precisam corresponder às mudanças decorrentes do pluralismo, do comércio internacional, da abertura cultural e social.

A Segunda Parte explora a ampla variedade de gêneros que professores e alunos podem usar para o desenvolvimento de habilidades, competências e conhecimentos. Esta parte compreende sete capítulos (do $4^{\circ}$ ao $10^{\circ}$ ), compondo o corpo principal da obra em termos de áreas de conteúdo.

O Capítulo 4 é de autoria de Illig-Avilés e começa por mostrar como a ficção histórica pode ser uma ponte para a construção da cidadania, da criatividade, e de outras habilidades, recorrendo a várias estratégias. Lembra que há uma rica bibliografia, nos USA, de obras de ficção baseadas na história, escritas especialmente para jovens, com catálogos especiais com sugestões didáticas. Esta não é a realidade com que convivem os professores brasileiros.

Lembrando que um dos problemas cruciais com que se ocupam os especialistas em leitura é o jovem que sabe ler mas não o faz, Moss começa o capítulo seguinte. Nele trata de como estimular a leitura de livros comerciais que não são de ficção, como recurso de grande potencial para motivar o jovem a ler. Trata-se de livros que podem ou não ser usados como meios formais de instrução. Destaca como pontos a considerar: a livre escolha dos livros, os professores lerem o livro todo em voz alta, comparar livros com filmes, ler livros ilustrados, fazer trabalhos de arte relacionados com a leitura, ler outros materiais correlatos. São formas de obter e fortalecer a motivação para a leitura entre jovens. O tema tem continuidade no Capítulo 6, no qual Carlson mostra como livros do referido tipo podem ser associados com projetos de pesquisa com êxito na formação de adolescentes e jovens adultos. O primeiro passo é, novamente, a escolha de livros para início da pesquisa; cuidados no conduzir a pesquisa, especialmente registros de dados; cuidado com os registros bibliográficos e com a redação da pesquisa.

No Capítulo 7, Lesenne apresenta o uso de biografias e autobiografias para desenvolvimento do leitor e de seu conhecimento. Lembra os muitos benefícios que esta leitura em sala de aula pode trazer. Orienta como fazer esse uso, como desenvolver o espírito crítico e investigativo a partir desses textos. A seguir, Chance enfoca o uso da poesia (Capítulo 8) como formação de leitores, começando por seu papel no cantar o amor, na comunicação afetiva, na perda do amor, no patriotismo e no próprio envolvimento com o expressar-se pela poesia. O tema é retomado por Mitchell (Capítulo 9), que trata da relação ouvir e desejar escrever poesias, aspecto a ser explorado pelo professor. Este desejo também pode ser por querer escrever sobre as poesias. Apresenta um quadro, inicialmente proposto por Elliot, sobre 12 maneiras pelas quais a pessoa pode responder a um poema, as quais constituem uma orientação para qualquer leitor e que, nas mãos de um professor competente, podem se constituir em todo um curso.

O capítulo seguinte, assinado por Fuhler ( $\left.n^{\circ} 10\right)$, trata do uso de livros de arte (ilustrados) como ferramenta integrante de todo o currículo acadêmico, estimulando a criatividade, fortalecendo o comportamento do leitor de 
texto e do leitor de imagem, fortalecendo as relações entre ilustração-texto-escrita, bem como estabelecendo a integração com outras áreas do conhecimento, tais como estudos sociais, história, literatura, estudos de ambiente etc.

A última sessão do livro é composta por dois capítulos que enfocam os autores. Realmente, estabelecer contato direto entre estudantes e autores é uma prática educacional bastante valorizada, mas seu êxito depende de um cuidadoso planejamento e uso adequado das tecnologias disponíveis, para que não se torne um episódio sem maiores conseqüências para o desenvolvimento do leitor.

No Capítulo 11, Dorfman trata do uso de estratégias que tornam o estudo de autor uma atividade realmente produtiva. Oferece atividades de efeitos positivos já comparados, apresenta como exemplo um estudo de autor (Polacco) para orientar trabalhos nessa área. O tema continua a ser trabalhado no último capítulo por Elliot, Matter, Spinelli \& Cheripko. Desta feita, é a visita a autores que é focalizada. Para ela ocorrer há uma série de atividades que devem começar um ano, dois ou três meses, um mês, duas semanas, uma semana e imediatamente antes da apresentação. Em cada período dos arrolados são apresentadas seqüências diversas de atuação. Durante o evento padrões específicos de comportamento devem estar presentes. Após o encontro com o autor há uma série de atividades a serem concretizadas e avaliações a serem feitas. Roteiros e sugestões específicas são apresentados; são úteis a professores de todos os níveis e também para pesquisadores. Avaliações são feitas para assegurar o êxito da visita em termos acadêmicos, de desenvolvimento pessoal e de pesquisa dos procedimentos.

Endereços Web sobre literatura para jovens adultos, um glossário de idéias, além dos índices já referidos auxiliam o leitor.

A bibliografia de todos os capítulos é rica e sugestiva; compreende, além das referências a textos científicos, as relativas a obras literárias e muitos endereços de buscas eletrônicas que são úteis aos interessados.

Trata-se de obra de grande valia para quantos trabalham com a leitura, tendo por alvo $o$ adolescente e o jovem adulto. Embora o foco principal seja a literatura, os procedimentos, as estratégias e as técnicas podem ser usados em níveis de escolaridade que vão do ensino fundamental até a pós-graduação. Além disso alguns se prestam também à biblioterapia.

Recebido para publicação em 06 de agosto de 2002 e aceito em 22 de outubro de 2002. 